\title{
ANTIOXIDANT ACTIVITY OF SELECTED NATURAL MEDICINES USED IN NEPAL
}

\author{
KP Baral ${ }^{1 *}$ and P Basnet ${ }^{2}$ \\ ${ }^{1}$ Department of Pharmaceutical Sciences, School of Health and Allied Sciences, Pokhara University, Lekhnath, Kaski, Nepal. \\ ${ }^{2}$ Head of IVF Laboratory, Department of Obstetrics and Gynecology, University Hospital of North Norway, Tromso, Norway. \\ *Correspondence to : Ms Kalpana Parajuli Baral, Department of Pharmaceutical Sciences, School of Health and Allied Sciences, Pokhara University, \\ P.O.Box 427, Lekhnath, Kaski, Nepal.Email: kalpanaprjl@gmail.com
}

\begin{abstract}
Diminished antioxidant defence or increased production of reactive oxygen and nitrogen species in the biological system can result into oxidative stress which can cause damage to deoxyribonucleic acid (DNA), proteins, lipids and as a result different disease states arise like cancer, neurodegenerative diseases, rheumatoid arthritis. Antioxidants from different plant resources can significantly delay or prevent oxidation of the substrate and hence prevents from various diseases. Therefore, present research was focused in search of potent natural antioxidants. For the study, methanolic extracts of twenty-five common natural medicines, mostly spices were screened using 1,1-diphenyl-2-picrylhydrazyl (DPPH) radical for their antioxidative activities. Among them, extracts of Chebulae Fructus, Terminalia Billericae Fructus, Phyllanthi Fructus, Cinnamomi Cortex, Arecae Semen, Pericarpium Punicae Granati, Syzygiae Fructus, Rhei Rhizoma, Pterocarpi Lignum and Santali Lignum Albi showed potent antioxidative activity with EC50 values being $1.5,2.1,1.4,2,1.5,1.45,2.7,2.9,3,3.8 \mu \mathrm{g} / \mathrm{mL}$, respectively. Ascorbic acid (EC50: $2.6 \mu \mathrm{g} / \mathrm{mL}$ ) was used as positive control. Therefore, consumers can increase their intake of foods rich in antioxidant compounds that can lower the risk of chronic health problems.
\end{abstract}

Key Words: Free radicals, ROS, RNS, antioxidants, DPPH \& natural medicines.

\section{INTRODUCTION}

Reactive oxygen species (ROS) and reactive nitrogen species (RNS) are the collective terms often used by scientists to include not only the oxygen and nitrogen radicals such as superoxide $\left(\mathrm{O}_{2}^{*}\right)$ hydroxyl $\left(\mathrm{OH}^{*}\right)$ nitric oxide $\left(\mathrm{NO}^{*}\right)$ nitrogen dioxide $\left(\mathrm{NO}_{2}^{*}\right)$ but also some non-radical derivatives of oxygen and nitrogen like hydrogen peroxide $\left(\mathrm{H}_{2} \mathrm{O}_{2}\right)$, hypochlorous acid $(\mathrm{HOCl})$, ozone $\left(\mathrm{O}_{3}\right)$, peroxynitrite $\left(\mathrm{ONOO}^{-}\right)$nitrous acid $\left(\mathrm{HNO}_{2}\right)$, dinitrogen trioxide $\left(\mathrm{N}_{2} \mathrm{O}_{3}\right) .{ }^{1}$ Free radicals are generated during oxidative metabolism and energy production in the biological system. ${ }^{2}$ Rapid production of free radicals can lead to oxidative damage to biomolecules and may cause disorders such as cancer, diabetes, inflammatory disease, asthma, cardiovascular diseases, neurodegenerative diseases, and premature aging. ${ }^{3}$

The oxidative stress may take place at different sites, different times, and by different mechanisms, and hence various antioxidants with different functions constituting a defence system against oxidative stress in vivo must be required. ${ }^{4}$ Antioxidant defences comprise enzymes like superoxide dismutase, catalase, peroxidase; proteins like transferrins, haptoglobins, haemopexin and metallothionein; low-molecularmass agents like glutathione, bilirubin and uric acid; and antioxidants from diet like ascorbic acid and $\alpha$-tocopherol. ${ }^{1}$ In recent years, the antioxidative property of food constituents has been seriously noted by medical and nutritional experts. ${ }^{5}$ Natural antioxidants from natural foods such as herbs, vegetables, fruits, oilseeds, spices, green tea, and cereals have been studied. ${ }^{6}$

Antioxidant-based drug formulations are being used for the prevention and treatment of complex diseases like atherosclerosis, stroke, diabetes, Alzheimer's disease and cancer. Spices and herbs are recognized as sources of natural antioxidants and thus play an important role in the chemoprevention of diseases and aging. ${ }^{7}$ Spices and other medicinal herbs are regularly consumed by people especially in Asian countries like Nepal and India. So, the present study attempted to screen the antioxidative activity of commonly used spices and some other herbs used in Nepal.

\section{MATERIALS AND METHODS}

Chemicals and Equipments

All organic solvents and chemicals used in the study were of analytical grades. 1,1-diphenyl-2-picryl hydrazyl (DPPH) was purchased from Wako Pure Chemicals Co. Ltd., Osaka, Japan. HPLC grade methanol used for the DPPH assay was from Merck Limited, India. Ascorbic acid was the product of Qualigens Fine Chemicals, India. Silica gel for column chromatography was of 60-120 mesh from Qualigens Fine Chemicals, India. Silica gel for Thin Layer Chromatography (TLC) was Silica gel G from Merck Company Limited, India. UV-2101 Spectrophotometer 
was manufactured by Auxylab, S.L., India.

Collection of Natural Medicines

All the natural medicines were collected from the crude drug market at Bindhyabasini Tole, Pokhara. The authentic samples of these natural medicines were preserved in the Museum of Materia Medica, School of Health and Allied Sciences, Pokhara University. The list of the natural medicines is given in Table 1.

Table 1: List of the natural medicines included in the study

\begin{tabular}{|c|c|c|c|c|c|}
\hline $\mathbf{S N}$ & Natural medicine & Local name & Biological source & Family & $\begin{array}{l}\text { Crude } \\
\text { drug } \\
\text { voucher } \\
\text { no. }\end{array}$ \\
\hline 1 & Cinnamomi Cortex & Dalchini & Cinnamomum zeylanicum Nees & Lauraceae & 361 \\
\hline 2 & Syzygiae Fructus & Lwang & Syzygium aromaticum Merril et Peery & Myrtaceae & 362 \\
\hline 3 & Foeniculi Fructus & Saunf & Foeniculum vulgare Mill & Umbelliferae & 363 \\
\hline 4 & Glycyrrhizae Radix & Jethimadhu & Glycyrrhizae glabra Linn. & Fabaceae & 364 \\
\hline 5 & Picrorhizae Rhizoma & Kutki & Picrorhizae scrophulariiflora Pennell & Scrophulariaceae & 365 \\
\hline 6 & Zingiberis Rhizoma & Sutho & Zingiber officinalis Willd. Rosc. & Zingiberaceae & 366 \\
\hline 7 & Rhei Rhizoma & Padamchal & Rheum palmatum Linn. & Polygonaceae & 367 \\
\hline 8 & Chebulae Fructus & Harro & Terminalia chebula Retz. & Combretaceae & 368 \\
\hline 9 & Terminaliae Billericae Fructus & Barro & Terminalia bellerica (Gaetrn) Roxb. & Combretaceae & 369 \\
\hline 10 & Phyllanthi Fructus & Amala & Phyllanthus embellica Linn. & Euphorbiaceae & 370 \\
\hline 11 & Capsici Fructus & Khursani & Capsicum annum Linn. & Solanaceae & 371 \\
\hline 12 & Curcumae Rhizoma & Besar & Curcuma longa Linn. & Zingiberaceae & 372 \\
\hline 13 & Arecae Semen & Supari & Areca catechu L. & Palmae & 373 \\
\hline 14 & Amomi Semen & Alainchi & Amomum subulatum Roxb. & Zingiberaceae & 374 \\
\hline 15 & Zanthoxyli Fructus & Timur & Zanthoxylum armatum DC & Rutaceae & 375 \\
\hline 16 & Piperis Fructus & Marich & Piper nigrum L. & Piperaceae & 376 \\
\hline 17 & Trigonellae Semen & Methi & Trigonella foenum-graecum L. & Leguminosae & 377 \\
\hline 18 & Pericarpium Punicae Granati & Anar & Punica granatum L. & Punicaceae & 378 \\
\hline 19 & Withaniae Radix & Ashvagandha & Withania somnifera Dunal & Solanaceae & 379 \\
\hline 20 & Pterocarpi Lignum & Raktachandan & Pterocarpus santalinus L.f. & Leguminosae & 380 \\
\hline 21 & Santali Lignum Albi & Srikhanda & Santalum album L. & Santalaceae & 381 \\
\hline 22 & Cumini Fructus & Jira & Cuminum cyminum L. & Umbelliferae & 382 \\
\hline 23 & Coriandri Fructus & Dhaniya & Coriandrum sativum L. & Umbelliferae & 383 \\
\hline
\end{tabular}




\begin{tabular}{|l|l|l|l|l|l|}
\hline 24 & Dactylorhizae Rhizoma & Panchaunle & Dactylorhiza hatagirea (D. Don) Soo & Orchidaceae & 384 \\
\hline 25 & Brassicae Semen & Sursyu & Brassica alba L. & Cruciferae & 385 \\
\hline
\end{tabular}

\section{Preparation of Extracts for DPPH Radical Scavenging Activity}

Ground dried samples of each natural medicine $(30 \mathrm{~g})$ were extracted with methanol $(2 \times 180 \mathrm{~mL})$ at room temperature for 24 hours. The extracts were concentrated to dryness under rotatory evaporator.

\section{Determination of DPPH Radical Scavenging Capacity}

DPPH radical scavenging activity was measured according to the method of Hegazi et al.8 with slight modifications. One $\mathrm{mL}$ of methanolic solution of each extract at various concentrations $(10 \mu \mathrm{g} / \mathrm{mL}, 50 \mu \mathrm{g} / \mathrm{mL}$ and $100 \mu \mathrm{g} / \mathrm{mL})$ was mixed with $1 \mathrm{~mL}$ of methanolic solution of DPPH (approx. $60 \mu \mathrm{M}$ ). The reaction mixture was shaken vigorously and left for 30 minutes at room temperature. The radical scavenging (antioxidative) activity of extracts corresponding to the scavenging of DPPH radical was measured at $520 \mathrm{~nm}$ by absorbance of UV spectrophotometer.

Radical scavenging activity $(\%)=\frac{(\text { control absorbance }- \text { extract absorbance) }}{\text { control absorbance }} \times 100 \%$

where, control is the test solution without extract.

Ascorbic acid was used as the positive control (distilled water was used as the solvent).

Those natural medicines which showed potent radical scavenging activity were again analysed for the DPPH radical scavenging at concentration $1 \mu \mathrm{g} / \mathrm{mL}, 2 \mu \mathrm{g} / \mathrm{mL}, 5 \mu \mathrm{g} / \mathrm{mL}, 10 \mu \mathrm{g} / \mathrm{mL}, 15 \mu \mathrm{g} / \mathrm{mL}$ and $20 \mu \mathrm{g} / \mathrm{mL}$. From these data, calibration curve was plotted and Effective Concentration $\left(\mathrm{EC}_{50}\right.$ ) value was calculated. The antioxidative activity was expressed by $\mathrm{EC}_{50}$. The $\mathrm{EC}_{50}$ value is defined as the concentration $(\mu \mathrm{g} / \mathrm{mL})$ of the extract required for $50 \%$ reduction of the DPPH radical absorbance.

\section{RESULTS AND DISCUSSION}

Twenty-five commonly used natural medicines listed in Table 1 were analysed for their antioxidative activity. Methanolic extracts of these natural medicines were prepared in various concentrations $(10 \mu \mathrm{g} / \mathrm{mL}, 50 \mu \mathrm{g} / \mathrm{mL}$ and $100 \mu \mathrm{g} / \mathrm{mL})$ and DPPH radical scavenging activity was determined. The DPPH radical scavenging activity of these natural medicines was expressed as \% DPPH radical scavenged. Ascorbic acid was used as the positive control.

Methanolic extracts of Cinnamomi Cortex, Syzygiae Fructus, Rhei Rhizoma, Chebulae Fructus, Terminalia Billericae Fructus, Phyllanthi Fructus, Arecae Semen, Pericarpium Punicae Granati, Pterocarpi Lignum, and Santali Lignum Albi showed potent antioxidative activity (Figure 1). These extracts were further analysed to calculate the $\mathrm{EC}_{50}$ value.

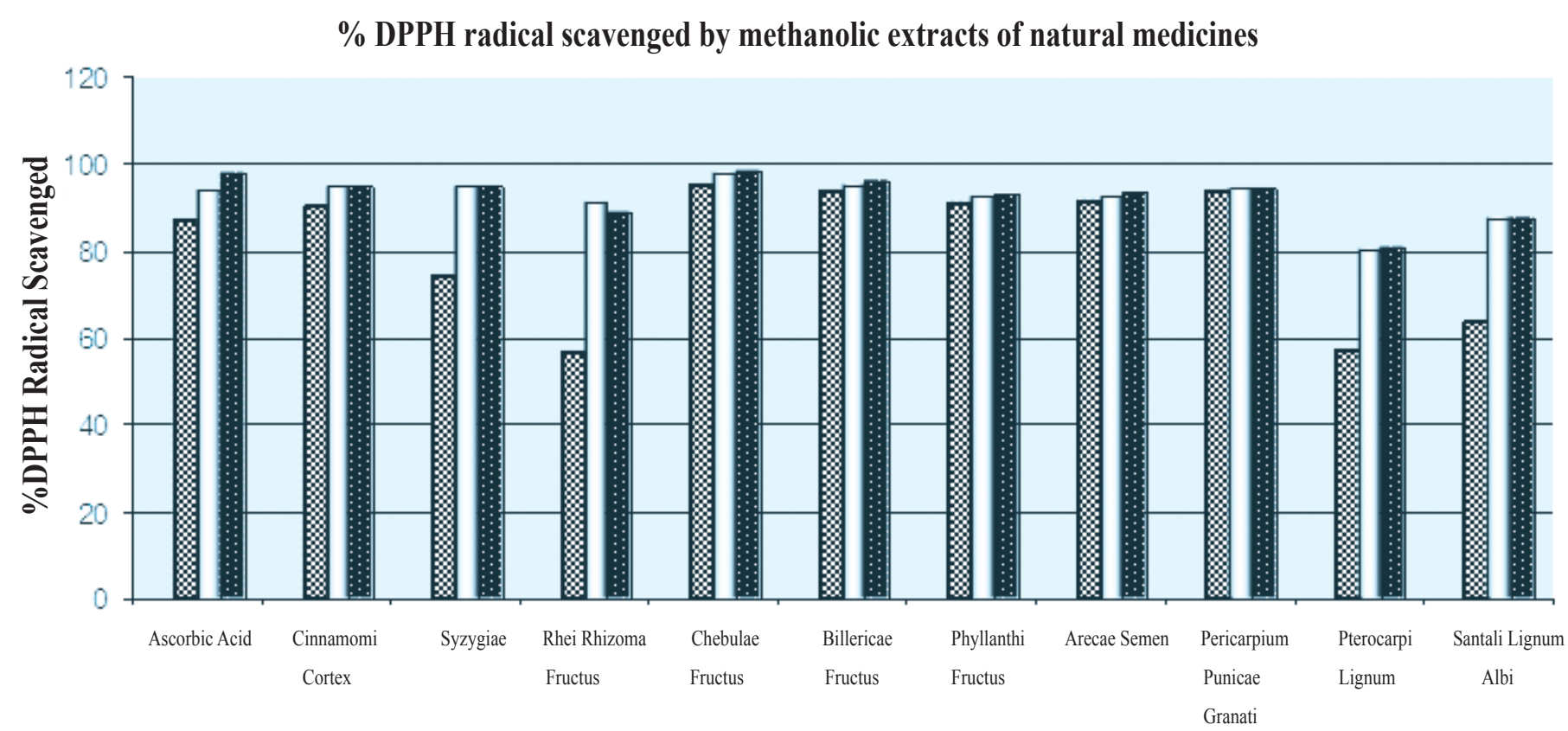

《) $5 \mu \mathrm{g} / \mathrm{mL} \quad \square 25 \mu \mathrm{g} / \mathrm{mL} \quad \mathrm{ag} / \mathrm{g} / \mathrm{mL}$ 
Methanolic extracts of Foeniculi Fructus, Glycyrrhizae Radix, Picrorhizae Rhizoma, Zingiberis Rhizoma, Capsici Fructus, Curcumae Rhizoma, Amomi Semen, Zanthoxyli Fructus, Piperis Fructus, Trigonellae Semen, Withaniae Radix, Cumini Fructus, Coriandri Fructus, Dactylorhizae Rhizoma, and Brassicae Semen showed relatively less potent radical scavenging activity (Figure 2).

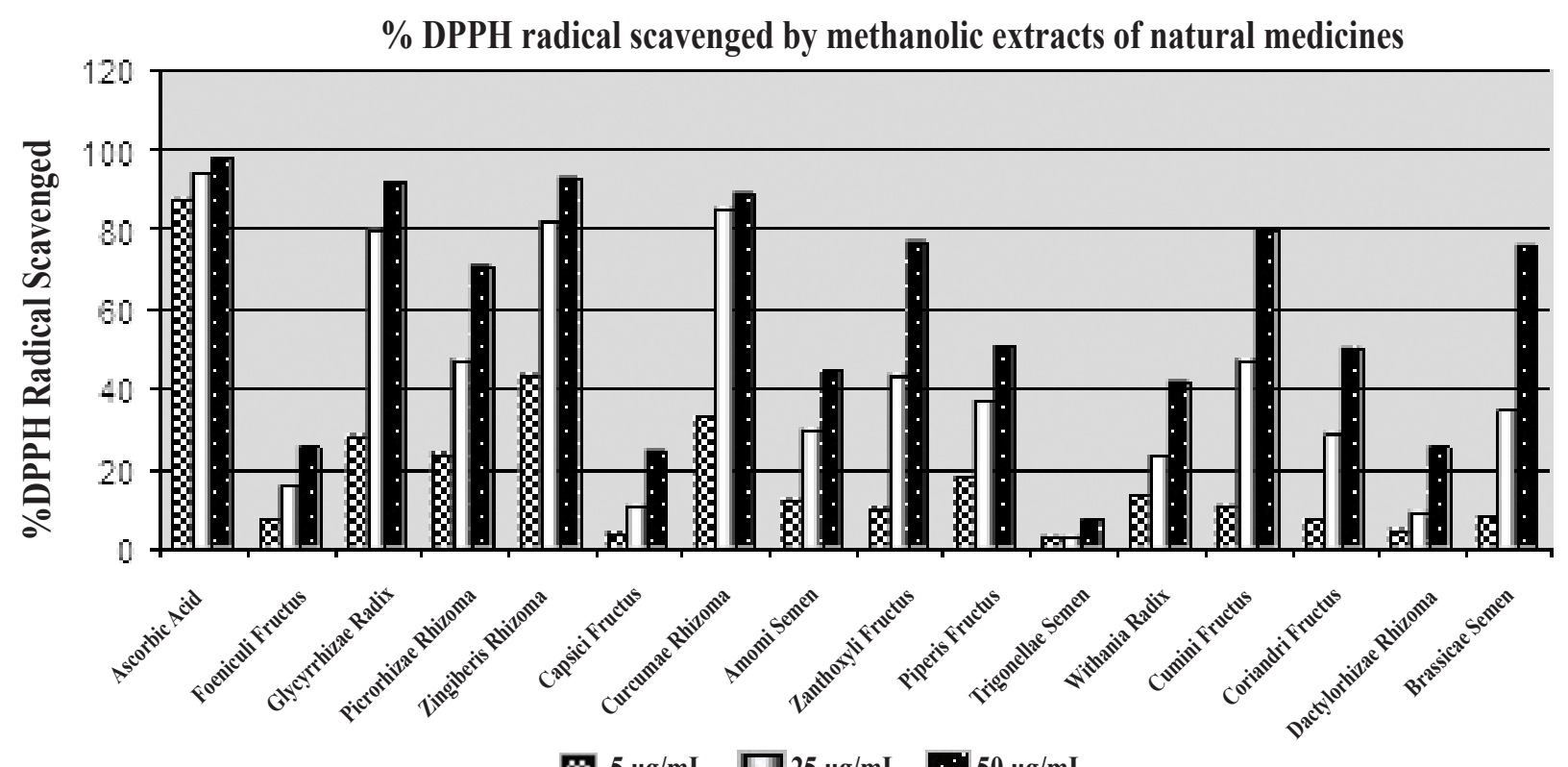

因 $5 \mu \mathrm{g} / \mathrm{mL} \square 25 \mu \mathrm{g} / \mathrm{mL} \quad: \quad: 50 \mu \mathrm{g} / \mathrm{mL}$

Figure 2: DPPH radical scavenging activity of natural medicines that showed less potent antioxidative activity

For those extracts which showed potent free radical scavenging activity, the concentration of the extract solutions were prepared as $1,2,5,10,15$, and $20 \mu \mathrm{g} / \mathrm{mL}$ and $\mathrm{EC}_{50}$ values were calculated from calibration curve. Chebulae Fructus $\left(\mathrm{EC}_{50} 1.5 \mu \mathrm{g} / \mathrm{mL}\right)$, Terminalia Billericae Fructus $\left(\mathrm{EC}_{50} 2.1 \mu \mathrm{g} / \mathrm{mL}\right)$, Phyllanthi Fructus $\left(\mathrm{EC}_{50} 1.4 \mu \mathrm{g} / \mathrm{mL}\right)$, Cinnamomi Cortex $\left(\mathrm{EC}_{50} 2.0 \mu \mathrm{g} / \mathrm{mL}\right), \mathrm{Arecae}$ Semen $\left(\mathrm{EC}_{50} 1.5 \mu \mathrm{g} / \mathrm{mL}\right)$, Pericarpium Punicae Granati $\left(\mathrm{EC}_{50} 1.45 \mu \mathrm{g} / \mathrm{mL}\right)$ were more potent than Ascorbic acid $\left(\mathrm{EC}_{50} 2.6 \mu \mathrm{g} / \mathrm{mL}\right)$. Syzygiae Fructus $\left(\mathrm{EC}_{50} 2.7 \mu \mathrm{g} / \mathrm{mL}\right)$, Rhei Rhizoma $\left(\mathrm{EC}_{50} 2.9 \mu \mathrm{g} / \mathrm{mL}\right)$, Pterocarpi Lignum $\left(\mathrm{EC}_{50} 3 \mu \mathrm{g} / \mathrm{mL}\right)$ and Santali Lignum Albi $\left(\mathrm{EC}_{50} 3.8 \mu \mathrm{g} / \mathrm{mL}\right)$ were relatively less potent than ascorbic acid (Figure 4). Phyllanthi Fructus extract was the most potent.

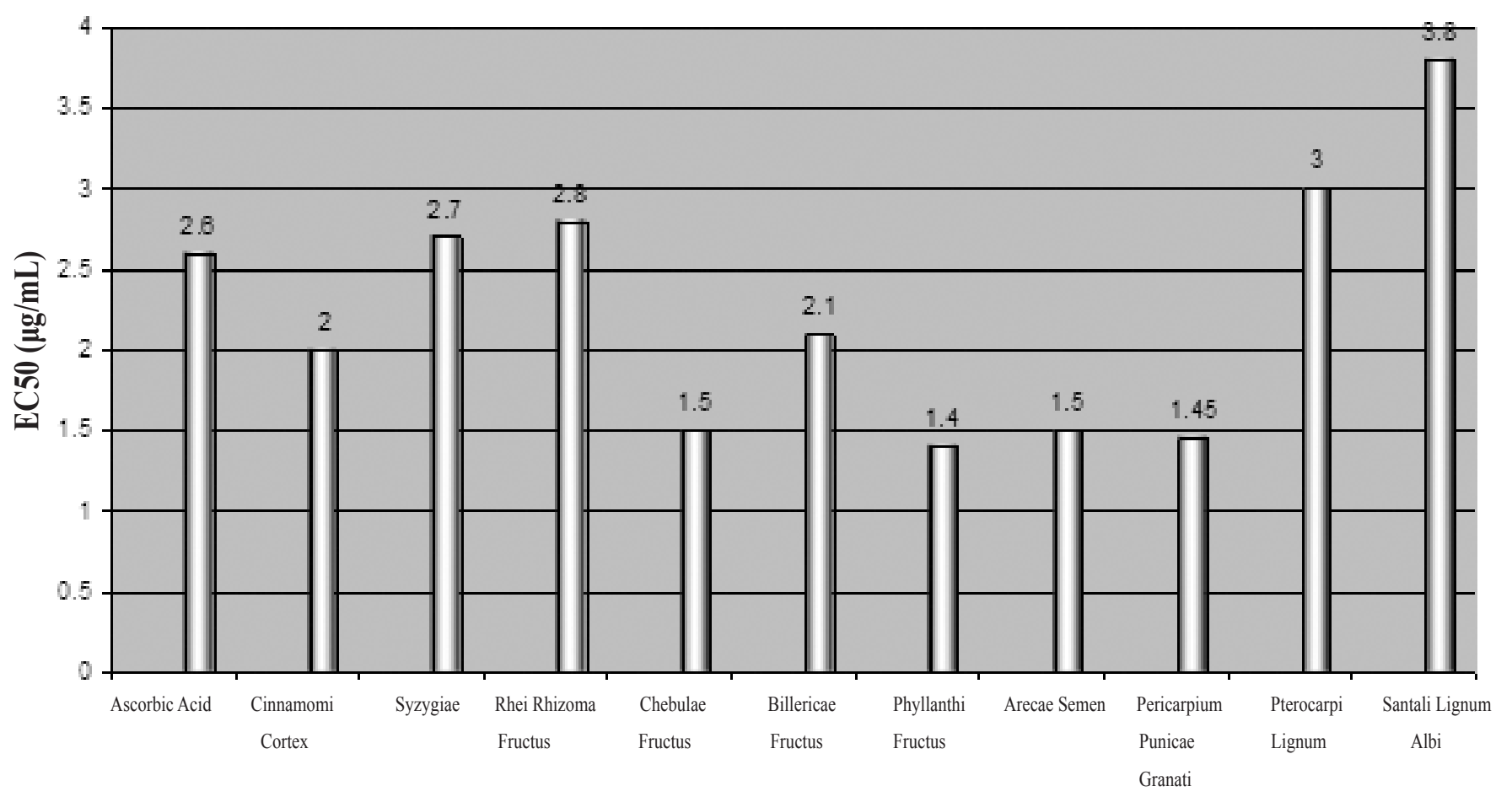

Figure 3: $\mathrm{EC}_{50}$ value of natural medicine extracts and ascorbic acid 
In the particular study, DPPH free radical scavenging assay was used since it is a simple and acceptable method to evaluate antioxidant activity of plant extracts. In the presence of an antioxidant, DPPH radical form stable molecules by gaining one more electron or hydrogen atom and the absorbance decreases thus has applications in determination of free radical scavenging activity of natural products as well as synthetic compounds. ${ }^{9}$ Lower $\mathrm{IC}_{50}$ value indicates higher antioxidant activity. ${ }^{10}$

So, our study proved the antioxidant activity of selected spices and herbs and it indicates that plant extracts showing higher antioxidant activity could be the significant source of natural antioxidant, which might be helpful in preventing the progress of various oxidative stresses and its related disorders.

\section{CONCLUSION}

Methanolic extracts of twenty-five commonly used Nepalese natural medicines were screened for their antioxidative activity by DPPH method. From the study it was found that six of the natural medicines Chebulae Fructus, Terminalia Billericae Fructus, Phyllanthi Fructus, Cinnamomi Cortex, Arecae Semen, and Pericarpium Punicae Granati were even more potent than the positive control, ascorbic acid. So these natural sources of antioxidants can be used to prevent or treat different types of diseases which might be cheaper and safer than the other synthetic antioxidants.

\section{REFERENCES}

1. Halliwell B, Gutteridge JMC. Free Radicals in Biology and Medicine, 3rd Edition, Oxford University Press Inc, New York 1999; 27:105, 249, 251.

2. Packer L, Witt EH, Tritschler HJ. Alpha-lipoic Acid as a Biological Antioxidant, Free Radic. Biol. Med. 1995; 19: $227-$ 250 .
3. Ghimire BK, Seong ES, Kim EH, Ghimeray AK, Yu CY, Ghimire BK, Chung M. A Comparative Evaluation of the Antioxidant Activity of Some Medicinal Plants Popularly Used in Nepal. J Med Plants Res 2011; 5: 1884-1891.

4. Cadenas E, Packer L. Handbook of Antioxidants, Marcel Dekker, Inc., New York 1996; iv.

5. Asai A, Nakagawa K, Miyazawa T. Antioxidative Effects of Turmeric, Rosemary and Capsicum Extracts on Membrane Phospholipid Peroxidation and Liver Lipid Metabolism in Mice. Biosci Biotechnol Biochem 1999; 63: 2118-2122.

6. Song HS, Ukeda H, Sawamura M. Antioxidative Activities of Citrus Peel Essential Oils and Their Components against Linoleic Acid Oxidation. Food Sci Technol Res 2001; 7: 50-56. 7. Khalaf NA, Shakya AK, Al-Othman A, El-Agbar Z, Zarah H. Antioxidant Activity of Some Common Plants. Turk J Biol 2008; 31: 51-55.

8. HegaziAG, EIHaddy FKA. Egyptian Propolis. Antioxidant, Antimicrobial Activities and Chemical Composition of Propolis from Reclaimed Lands. Z. Naturforsch 2002; 57: 395-402.

9. Bhuiyan MAR, Hoque MZ, Hossain SJ. Free Radical Scavenging Activities of Zizyphus mauritiana. World Journal of Agriculture Sciences 2009; 5: 318-322.

10. Pourmorad F, Hosseinimehr SJ, Shahabimajd N. Antioxidant Activity, Phenol and Flavonoid Contents of Some Selected Iranian Medicinal Plants. Afr J Biotechnol 2006; 5: 1142-1145. 